\title{
Suppression of brown blotch disease by tolaasin inhibitory factors
}

\author{
Yeong-Bae Yun ${ }^{1}$ (D) $\cdot$ Min-Hee Kim ${ }^{1}$ (D) $\cdot J^{-H y e ~}$ Han $^{1}$ (D) $\cdot$ Young-Kee Kim $^{1}$ (D)
}

\section{톨라신 저해 물질을 이용한 갈반병의 억제}

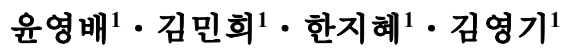

Received: 9 June 2017 / Accepted: 15 June 2017 / Published Online: 30 June 2017

(C) The Korean Society for Applied Biological Chemistry 2017

\begin{abstract}
Tolaasin, a $1.9 \mathrm{kDa}$ peptide toxin, is produced by Pseudomonas tolaasii and causes the brown blotch disease of cultivated oyster mushroom. It forms pores on the membrane and thus destroys cellular membrane structure, seriously reducing the productivity of mushroom cultivation. The mechanism of tolaasininduced cytotoxicity is not known in detail. However, it has been reported to form a pore structure in the cytoplasmic membrane through the molecular multimerization. Therefore, food additives which can interact with tolaasin molecules may inhibit the pore formation by hydrophobic interactions with tolaasin molecules. In this study, various food additive materials have been identified as inhibitors of the tolaasin activity and named tolaasin-inhibitory factors (TIF). Most of TIFs are emulsifying agents for food processing procedures. Among various TIFs, polyglycerol and sucrose esters of fatty acids blocked effectively the cytotoxicity of tolaasins at the concentrations $10^{-4}-10^{-5} \mathrm{M}$. These TIFs also successfully suppressed the blotch disease development in the shelf cultivation of oyster mushroom.
\end{abstract}

Keywords Oyster mushroom (Pleurotus ostreatus) $\cdot$ Peptide toxin $\cdot$ Pore formation $\cdot$ Pseudomonas tolaasii $\cdot$ Tolaasin

Young-Kee Kim $(\bowtie)$

E-mail: ykkim10@cbnu.ac.kr

${ }^{1}$ Department of Environmental and Biological Chemistry, Chungbuk National University, Cheongju, Chungbuk 28644, Republic of Korea

This is an Open Access article distributed under the terms of the Creative Commons Attribution Non-Commercial License (http://creativecommons. org/licenses/by-nc/3.0/) which permits unrestricted non-commercial use, distribution, and reproduction in any medium, provided the original work is properly cited.

\section{서 론}

갈반병은 인공재배버섯에서 Pseudomonas tolaasii에 의해 발생 하는 세균병으로 Tolaas(1915)에 의해 최초로 보고되었다. 이 병 은 버섯의 균사성장기에서 자실체 형성 초기에 P. tolaasi가 생 성하는 독소인 톨라신에 의해 발병한다(Peng 1986). 갈반병은 양송이버섯(Agaricus bisporus), 느타리버섯(Pleurotus ostreatus), 팽이버섯(Flammulina velutipes), 새송이버섯(Pleurotus eryngil) 등 수분을 많이 함유하는 부드러운 조직을 가진 버섯에 주로 발병한다(Kim 등, 1994). P. tolaasii는 습한 환경의 지하수나 대기를 통하여 버섯조직이나 버섯균사에 감염되며, 특히 생육이 불량한 조건에서 병원균에 대한 저항성이 약할 때 증식하여 톨 라신 분비로 병을 유발한다(Hutchison과 Johnstone 1993).

톨라신은 18 개의 아미노산과 지방산으로 구성되어 있으며, 분 자 내에 친수성과 소수성 부위를 동시에 갖는 양친매성 펩티드 독소로 계면활성제의 활성을 갖고 있다. 톨라신의 농도가 일정 수준이 되면 버섯 표면의 표면장력을 낮추며, 균은 버섯 세포 막 전체로 쉽게 확산된다(Hutchison과 Johnstone 1993). 톨라신 은 버섯세포막에 분자다중화결합을 통해 pore를 형성하여 세포 를 파괴하는 것으로 밝혀졌으며, 이러한 작용기작은 다른 poreforming 펩티드 독소들의 작용과 유사하다. 즉, 톨라신은 세포 막에 결합하고 막 내부로 유입된 후, 다중화결합으로 pore를 형 성하며, pore를 통한 전해질의 확산으로 삼투압이 교란되어 버 섯 세포의 파괴가 이루어진다(Cho와 $\mathrm{Kim} 2003)$.

갈반병이 발병하면 주변으로의 확산속도가 빨라서 재배단지 전체에 퍼질 수 있기 때문에 심각성이 크다. 이러한 갈반병 예 방을 위하여 농사용 지하수의 살균과 재배사의 훈증 소독 등의 방법이 사용되어 왔으며(Wong과 Preece 1985; Geels 등, 1991), 생물학적 방제 대책으로서 길항균과 박테리오파지가 실험적으 로 사용되었으나, 길항균은 기대할 만한 성과를 거두지 못하였 고(Nielson 등, 2002; Nybroe와 Sorensen 2004; Tajalipour 등, 2014), 파지의 효과는 항생제 내성균 연구와 함께 고려되어 긍 
정적인 결과를 얻고 있다 $(\mathrm{Kim}$ 등, 2011). 갈반병은 항생제의 사 용으로 방제될 수 있으나(Geels 1995), 버섯은 신선식품이기 때 문에 약제의 사용이 허용되지 않아 현재로는 효과적인 방제법 이 없는 실정이다.

국내에서 느타리버섯 갈반병에 관한 연구는 병에 의한 경제 적 손실에 비해 미흡한 수준이다. 그간에 수행한 갈반병 원인 균의 분리, 동정 및 특성연구에서 느타리버섯과 팽이버섯에서 병원균으로 P. agarici를 분리하였고(Shin과 Jeon 1991), 흰색침 강선 형성검정법, 버섯조직함몰검정법 등을 이용하여 P. tolaasii 가 병원성의 주 원인균주임을 확인하였다(Lee 등, 1997). 최근 국내외에서는 병원균의 세균학적, 병리학적 특성들에 더하여 병 원균이나 병원독소 톨라신과 관련된 유전자의 연구가 수행되고 있다(Mu 등, 2015; Desai 등, 2016).

본 연구는 갈반병 원인 독소인 톨라신의 활성화기작 중 분자 다중화결합 단계를 포함한 활성화과정의 저해를 통하여 갈반병 발생을 억제할 수 있는 방안 마련에 목적을 두고 수행하였다. 톨라신의 분자다중화결합을 억제할 수 있는 다양한 식품첨가물 을 대상으로 톨라신의 세포독성을 저해하는 물질을 탐색하였다. 이들 중 계면활성제의 효과는 매우 낮은 농도에서 보였으며, 버 섯조직함몰검정법(pitting test) 및 실제 느타리버섯의 균상재배 를 통해 이 물질의 갈반병 억제 효과를 측정하였다.

\section{재료 및 방법}

\section{톨라신 추출액 및 용혈활성 측정}

$25^{\circ} \mathrm{C}$ 의 Pseudomonas agar $\mathrm{F}$ (Bacto-peptone $10 \mathrm{~g}$, Bacto-tryptone $10 \mathrm{~g}, \mathrm{~K}_{2} \mathrm{HPO}_{4} 1.5 \mathrm{~g}, \mathrm{MgSO}_{4} 1.5 \mathrm{~g}$, Glycerol $10 \mathrm{~mL}$, Agar $15 \mathrm{~g} /$ $1 \mathrm{~L}$ 증류수) 액체 배지에 P. tolaasii 균주를 접종한 후, 정체기 에 도달하도록 18 시간 이상 진탕배양하고 배양액을 $8,000 \mathrm{rpm}$ 에서 30 분간 원심분리하여 균체를 제거하였다. 여기에 $30 \%$ 의 ammonium sulfate를 가하여 $4{ }^{\circ} \mathrm{C}$ 에서 1 시간동안 냉각하였다. 이 것을 SW 28 rotor (Beckman Instruments, Inc., Palo Alto, $\mathrm{CA}, \mathrm{USA}$ )를 이용하여 $20,000 \mathrm{rpm}$ 에서 1 시간동안 초원심분리하 여 침전을 얻었다. 침전으로 얻은 톨라신을 $10 \mathrm{mM}$ sodium phosphate buffer ( $\mathrm{pH}$ 7.0)로 녹여낸 다음, 실온에서 같은 용액 으로 4시간동안 투석하고 glass-teflon homogenizer로 균질화한 후 분액을 만들어 초저온냉동고 $\left(-70{ }^{\circ} \mathrm{C}\right)$ 에 보관하였다.

톨라신의 용혈활성 측정은 Cho 등(2000)의 방법에 따라 생 쥐의 적혈구를 이용하여 수행하였다. 용혈활성은 간략히 10 배 희석한 적혈구 반응용액에 톨라신을 $1 \mathrm{HU}$ 처리하여 30 분간 배 양 후 $600 \mathrm{~nm}$ 에서의 흡광도 감소를 측정하여 평가하였다.

\section{TIF의 톨라신 세포독성 저해 효과 측정}

Tolaasin inhibitory factors (TIFs)는 Mitsubishi-Kagaku Foods Corporation (Tokyo, Japan)과 Sakamoto Yakuhin Kogyo (Osaka, Japan) 제품을 남영상사를 통해 공급받았다. TIF에 의한 톨라 신의 용혈활성 저해는 각각의 TIF를 $\mathrm{pH} 7.4 \mathrm{HBS}$ 완충액에 $10^{-2}-10^{-5} \mathrm{M}$ 의 농도로 희석한 후 최종 반응용액의 $10 \%$ 가 되 도록 처리하여 측정하였다. TIF를 가한 적혈구 용액의 흡광 도를 시간별로 측정하여 톨라신 펩티드의 활성저해를 관측하 였다.

\section{버섯조직함몰검정법(Pitting test)을 이용한 TIF 효과 검정}

$\mathrm{TIF}$ 에 의한 갈반병 저해 효과를 확인하기 위해 버섯조직함몰검 정법(pitting test)을 이용하였다. 이 방법에서는 갈반 생성의 유 무가 확연하게 구분되는 $\operatorname{Gandy}(1968)$ 의 방법에 따라 양송이버 섯을 이용하였다. TIF 10 과 TIF 11 , TIF 12 , TIF 16 을 $10^{-2}$ $10^{-6} \mathrm{M}$ 로 다양하게 희석하고, 톨라신 추출액과 동량으로 혼합 하여 각각 $10 \mu \mathrm{L}$ 씩 양송이버섯 절단면에 점적하였다. 대조군에 는 톨라신 희석액 $10 \mu \mathrm{L}$ 를 점적하여 비교하였다. 처리된 버섯 은 조직의 건조 방지를 위해 멸균수로 적신 여과지가 있는 petri dish에 넣고 parafilm으로 밀봉하여 $25^{\circ} \mathrm{C}$ 항온기에 12-15시간동 안 배양하며 점적부위의 변색과 함몰 여부를 관찰하였다.

\section{느타리버섯 균상 재배를 통한 TIF 효과 검정}

느타리버섯 균사는 발효한 멸균톱밥배지에 $3.3 \mathrm{~m}^{2}$ 당 $10-15$ 병의 종균(한국버섯원균영농조합, 경기도 화성시)을 접종하고, 가로 1 $\mathrm{m}$, 세로 $2 \mathrm{~m}$ 의 크기와 적당한 모양으로 균상을 제작하여 배양 하였다. 약 3 주 간 배양 후, 균사가 균상의 밑바닥까지 완전히 자랐을 때, 저온자극을 위해 $16-18^{\circ} \mathrm{C}$ 로 감온하여 자실체 형성 을 유도하였다. 정상 자실체 및 병발생 면적을 비교하기 위하 여 색상선택법을 이용하였다(Lee 2017). 촬영한 사진의 색상을 Adobe Photoshop CS 프로그램을 이용하여 분석하면 정상 자실 체의 색상 범위는 R134-143, G132-141, B133-147이며, 노란색 이 만연한 갈반병 버섯의 색상 범위는 R165-199, G133-177, B94-146이다. 색상선택법을 통하여 위의 색상범위를 각각 선택 하고, 정상 자실체 및 갈반의 색을 가진 면적이 나타나면 선택 된 면적의 픽셀수를 계산하여 병발생 면적을 비교하였다.

\section{결 과}

\section{TIF의 종류 및 저해농도 측정}

톨라신에 의한 갈반병의 발생단계 중 어느 한 과정을 저해할 수 있다면 톨라신의 세포독성을 억제할 수 있을 것이며, 이러 한 저해물질을 TIF라 하고, 지방산의 여러 가지 식품첨가물을 대상으로 Sucrose 에스터 4가지, Polyglycerol 에스터 3가지, Glycerin 에스터 4가지, Sorbitan 에스터 2가지, Stearin 에스터 1 가지, Triglyceride 2 가지의 총 16 가지의 후보물질 중에 톨라신 과 결합하여 용혈활성을 억제할 수 있는 물질을 조사하였다 (Table 1). TIF의 농도를 $10^{-3}-10^{-6} \mathrm{M}$ 로 희석하며 톨라신의 용 혈활성 저해여부를 측정하였을 때(Fig. 1), 여러 TIF 후보물질 중 톨라신의 독성을 효과적으로 억제하는 물질은 주로 지방산 의 Sucrose 에스터와 Polyglycerol 에스터임을 확인하였다.

톨라신 분자들의 소수성 결합을 저해할 것으로 예측되었던 첨가물들은 모두 용혈활성 저해효과를 보였지만, 톨라신의 분자 다중화결합에 대한 저해 특성은 화합물에 따라 다소 차이를 보 였다. 그러나 톨라신의 세포독성 저해는 대부분 $10^{-4}-10^{-5} \mathrm{M}$ 의 농도 범위에서 나타났으며, 종류에 따라 최고 $10^{-3} \mathrm{M}$ 에서 최저 $10^{-6} \mathrm{M}$ 의 유효농도 범위를 나타내었다. 다만 TIF 9의 경우는 다른 화합물에 비해 용혈활성 저해 범위가 좁아 실제 버섯재배 에서의 적용은 어려울 것으로 확인하였다(자료 미제시). 한편, $\mathrm{TIF}$ 물질의 종류에 따라서는 약 $10^{-3} \mathrm{M}$ 이상의 높은 농도에서 용혈현상이 증가하는 것이 관측되기도 하였다. 
Table 1 Food additives used as TIF

\begin{tabular}{clcc}
\hline TIF & \multicolumn{1}{c}{ Compound } & MW & Commercial Product Name \\
\hline TIF 10 & Polyglycerol Fatty Acid Ester*1 & 1069 & Ryoto Sugar Ester SWA-10D \\
TIF 11 & Sucrose Fatty Acid Ester*1 & 470 & Ryoto Sugar Ester S-1695 \\
TIF 12 & Sucrose Fatty Acid Ester*1 & 594 & Ryoto Sugar Ester S-1570 \\
TIF 16 & Polyglycerol Fatty Acid Ester*2 & 1003 & SY-GLYSTER MM-750 \\
\hline
\end{tabular}

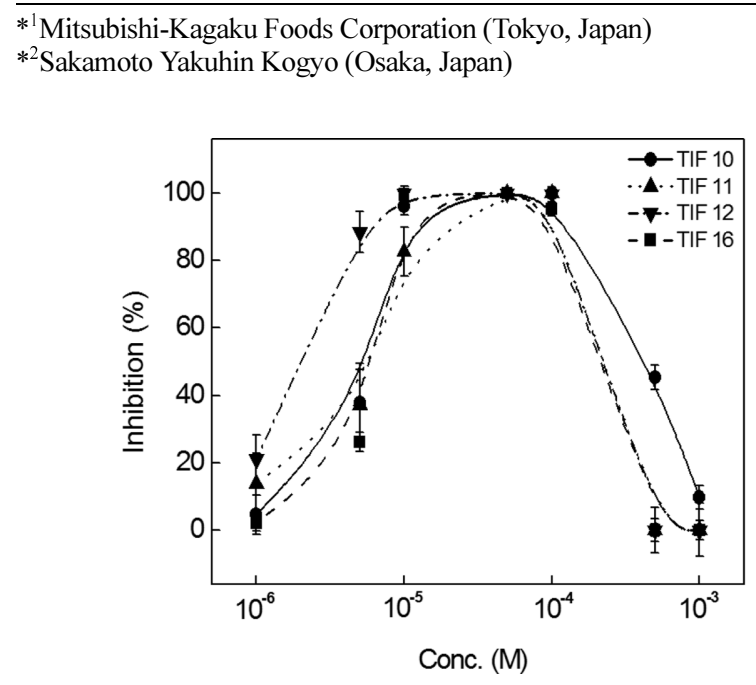

Fig. 1 Inhibitory effects of various TIFs on tolaasin-induced hemolysis. Inhibitions of tolaasin-induced hemolysis were measured in the presence of TIF at various concentrations ranging from $10^{-3}$ to $10^{-6} \mathrm{M}$

\section{버섯조직함몰검정법을 통한 TIF 효과 검중}

적혈구를 이용한 용혈활성 측정에서 $\mathrm{TIF}$ 는 $10^{-4}-10^{-5} \mathrm{M}$ 의 농도 범위에서 톨라신의 세포독성을 $100 \%$ 저해함을 확인하였다. TIF 의 우수한 세포독성 억제작용이 실제 버섯조직에서도 나타나는 지를 확인하기 위하여 버섯조직함몰검정법(pitting test)을 수행 하였다(Fig. 2). 대조군으로서 톨라신의 독성을 확인하기 위하여 표면에 톨라신 추출액만을 처리하였다. 동시에 TIF에 의한 톨 라신 세포독성 저해효과를 확인하기 위하여 TIF를 $10^{-4}-10^{-6} \mathrm{M}$ 의 농도로 처리하고 15 시간 경과 후에 버섯조직의 변색 및 함 몰 정도를 관측하였다.

톨라신만 처리한 경우 처리 부위의 조직이 파괴되면서 확연 하게 갈반이 나타나 버섯표면이 함몰되는 것을 확인할 수 있었 다. 반면에 농도별로 TIF를 톨라신과 혼합하여 처리한 부위에 서는 갈반 형성이 저해되었음을 확인하였다. TIF 10 과 TIF 11 의 경우 $10^{-4} \mathrm{M}$ 이상에서 갈반 형성을 완전히 저해하였고, $\mathrm{TIF}$ 12 의 경우에는 $10^{-2}-10^{-3} \mathrm{M}$ 의 농도범위에서 톨라신에 의한 갈 반과 함몰을 완전히 억제하였다. TIF 16 은 $10^{-4} \mathrm{M}$ 농도에서 갈 반의 생성 억제효과를 보였고 $10^{-6} \mathrm{M}$ 농도에서도 효과를 나타 냈다.

갈반의 형성을 가장 효과적으로 억제한 $\mathrm{TIF} 10, \mathrm{TIF} 11$, $\mathrm{TIF} 16$ 의 경우 처리농도로 환산하였을 때, 톨라신의 세포독성 을 저해하며 갈반 형성을 완벽하게 억제하는 $\mathrm{TIF}$ 의 농도는 약 $100 \mathrm{mg} / \mathrm{L}$ 이하로 $100 \mathrm{ppm}$ 이하의 매우 낮은 농도에서 갈반병 을 방제할 수 있음을 확인하였다. 이것은 용혈활성 저해효과 측 정에서와 마찬가지로 지방산 에스터계 식품첨가물인 TIF가 버

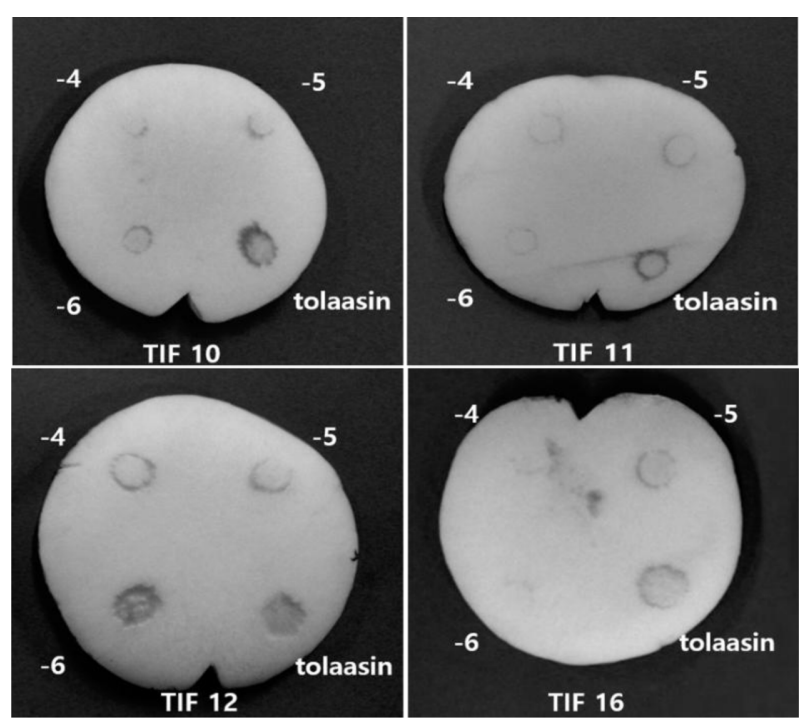

Fig. 2 Effects of various TIFs on the tolaasin-induced blotch formation by pitting test. Concentrations of TIFs were ranged from $10^{-6} \mathrm{M}$ to $10^{-4}$ $\mathrm{M}$ and the logarithmic concentrations of TIFs were expressed with -6 to -4 , respectively

섯조직에서 펩티드 독소인 톨라신의 병원성을 억제할 수 있음 을 보인 것으로, 실제 버섯 재배시에 TIF를 이용한다면 세균에 의해 발병하는 갈반병의 병리현상을 저해할 수 있다는 가능성 을 제시한다.

\section{버섯 재배를 통한 TIF 효과 검중}

균상재배를 통한 느타리버섯 재배에서는 충분한 양분 공급이 가 능하고 버섯생장에 공간적 제약이 없어 우수한 품질의 버섯을 생산할 수 있다. 또한 같은 균상배지에서 5 주기까지 버섯수확 이 가능하여 병재배법이나 봉지재배법에 비해 생산이 효율적이 다. 그러나 재배과정 중에 재배상이 공기 중에 노출되어 갈반 병 발생에 매우 취약하다는 단점이 있다. 따라서 본 연구에서 는 균상재배 방법을 이용하여 $\mathrm{TIF}$ 의 갈반병 억제효과를 확인하 였다. 갈반병은 세포벽이 발달하지 않은 자실체 발이 초기에 가 장 잘 발생하므로, 갈반병 발병과 방제 실험은 버섯의 크기가 $3 \mathrm{~cm}$ 미만으로 비교적 균일하게 발이하였을 때 수행하였다.

대조구와 비교하여 P. tolaasii 병원균을 처리한 구획의 버섯 생육은 약 40 시간 후 완전히 저해되었고, 자실체에 갈반이 만 연하게 나타나 조직이 건조되고 수축되는 병징이 뚜렷하게 나 타났다(Fig. 3). 그러나 병원균과 함께 TIF를 처리한 구획에서 는 일부 갈반의 증상이 관측되었으나, 병원균만 처리하였을 때 


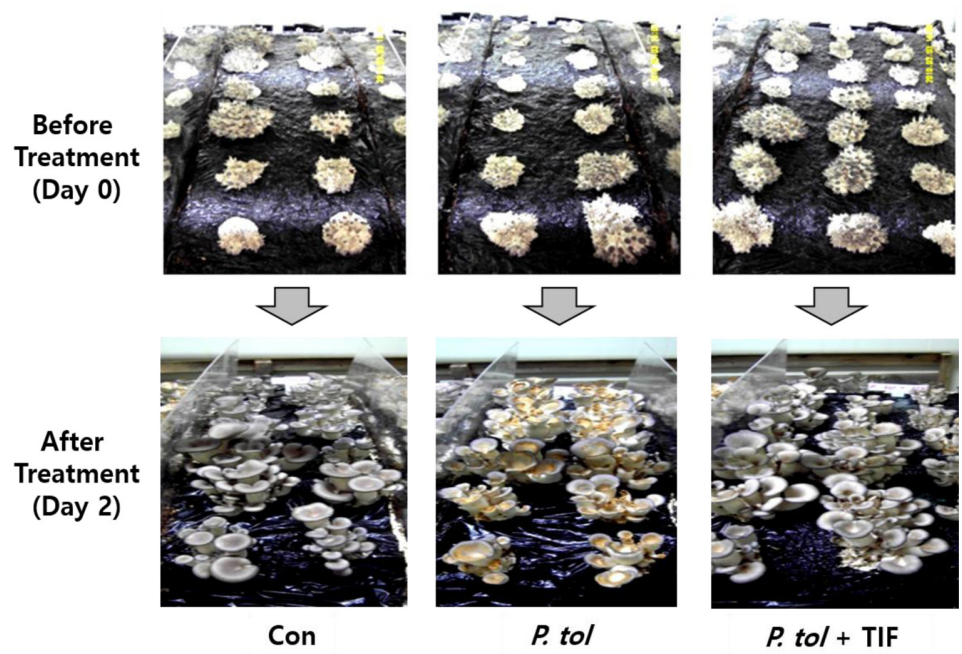

Fig. 3 Effects of $P$. tolaasii and TIF 11 on shelf-cultivated mushrooms. Blotch disease was observed on every bunch of oyster mushrooms treated with P. tolaasii (P. tol)

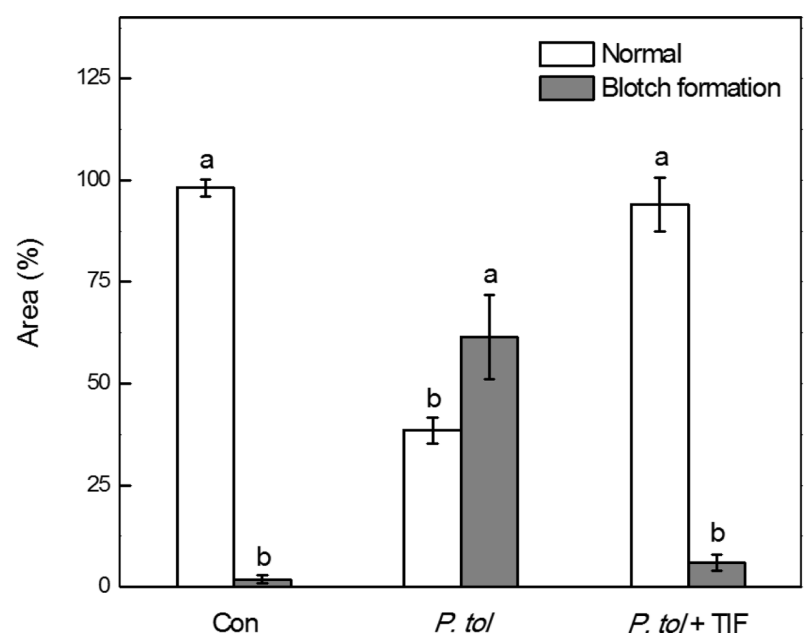

Fig. 4 Evaluated blotch formation area by the color analysis. The area of blotch disease was analyzed by the color comparison of mushrooms shown in Fig. 3. Data are expressed as mean \pm SE percentage of the results from four replicates. The different letters are statistically significant at $p<0.05$ (Turkey's Test, SAS Version 9.4)

와 비교하여 갈반병 발병이 현저하게 감소하였고, 대조구와 같 이 자실체의 계속적인 생장이 이루어졌다. 정상적으로 성장한 자실체는 윤기있는 회색으로 건강한 모습이었으나, 병징을 보이 는 자실체는 노란색을 강하게 띠고 있었다. 균상재배를 통해 키 운 느타리버섯에서 정상적인 자실체와 갈반이 발생한 자실체의 병징을 색상선택법을 이용하여(Lee 2017) 비교하였다(Fig. 4) 병원균을 처리한 경우에 정상적인 자실체의 색상면적은 대조군 과 비교하여 약 $40 \%$ 수준이었고, 병원균과 $\mathrm{TIF}$ 를 같이 처리한 버섯에서는 대조군과 거의 유사한 정상적인 자실체 면적을 보 였다. 그러나 갈반 발생을 나타내는 노란색의 면적은 병원균을 처리하여 갈반이 일어난 처리구에서 약 $60 \%$ 로 나타났으며, 대 조군과 $\mathrm{TIF}$ 를 처리한 구획에서 각각 약 $2 \%$ 와 $6 \%$ 로 나타났다.
이러한 결과는 TIF 처리로 P. tolaasii 균주가 분비하는 톨라신 펩티드의 세포독성이 거의 완전하게 저해되고 갈반의 생성이 억 제되어, TIF가 느타리버섯의 재배에서도 탁월한 갈반병 억제 능 력이 있음을 확인할 수 있었다.

\section{고 찰}

톨라신에 의한 갈반병의 발생은 버섯 세포막에 유입된 톨라신 분자의 채널 형성과 물질 이동 및 이에 따른 세포 내 삼투압 교란을 통한 세포막의 파괴, 조직의 괴사 등의 과정을 통하여 이루어짐이 알려져 있다(Rainey 등, 1991). 톨라신 저해제로 특 성이 밝혀진 $\mathrm{Zn}^{2+}$ 는 톨라신 pore의 통로를 막음으로써 활성을 저해하나(Cho 등, 2006), 본 연구의 TIF는 톨라신의 여러 작용 단계 중 분자다중체 형성 단계를 저해하여 버섯 세포막에 pore 형성을 막아 톨라신에 의한 갈반병의 발생을 억제하는 물질로 확인되었다. TIF에 의한 톨라신의 활성저해는 용혈활성 시험과 버섯조직함몰검정법(pitting test), 느타리버섯 균상재배 등에서 효과를 확인하였다.

용혈활성 시험에서 $\mathrm{TIF}$ 의 톨라신 세포독성 저해농도는 대부 분 $10^{-4}-10^{-5} \mathrm{M}$ 의 농도에서 얻어져 높은 저해 효과를 확인하였 다. 그러나 $\mathrm{TIF}$ 는 $10^{-3} \mathrm{M}$ 이상의 농도에서 오히려 용혈현상을 크게 증가시켰는데, 이는 TIF가 높은 농도에서 톨라신의 활성 과는 상관없이 그 자체가 계면활성제로 작용하여 적혈구 세포 막의 구조를 파괴함으로써 나타나는 현상으로 여겨진다. 적혈구 세포막은 극성물질들의 통과를 막고 carrier 단백질의 존재여부 에 따라 선택적 투과성을 가지나, 혈장의 삼투압이 감소하거나 세포막의 투과성을 증가시키는 물질이 막에 존재할 경우에는 적 혈구가 파괴되는 용혈현상이 발생한다(Nepal과 Rao 2011). 유 화제는 적혈구 세포막의 지질 성분을 녹이거나 교란함으로써 막 투과성을 증가시키며 막의 구조를 파괴하는 것으로 알려져 있 어(Nazari 등, 2012), 식품용 유화제로 알려진 TIF를 일정 농도 이상 첨가하였을 경우에 용혈현상이 발생한 것이다. 
갈반병 발생시 노란 갈색의 발색은 버섯세포 파괴시 활성화 되는 버섯 tyrosinase가 페놀성 화합물을 갈색 melanin으로 산 화시키면서 발생하는 현상으로(Soulier 등, 1993; Jolivet 등, 1995), tyrosinase는 P. tolaasii 감염시 활성화되어 갈반 형성 및 세포 파괴를 촉진한다(Soler-Rivas 등, 2001). 갈반병을 유발하 는 주요 세균인 P. tolaasii 6264 균주의 배양여액에서 농축한 톨라신을 얻은 후 양송이 버섯조직에 처리하면 버섯 표면에 함 몰 및 갈반을 유발한다. 그러나 톨라신과 미량의 TIF를 혼합 처리한 경우에는 톨라신에 의한 갈반의 생성 및 조직의 함몰을 효과적으로 억제하였으며, 처리한 TIF의 농도를 증가시킬수록 갈반 억제 효과가 증가하였다. 용혈활성시험보다 버섯조직함몰 검정에서 상대적으로 높은 농도의 $\mathrm{TIF}$ 에서 확연한 효과를 보였 으며, 이는 식물세포에는 세포벽이 존재하여 세포가 계면활성제 에 의해 쉽게 파괴되지 않기 때문일 것이다. 따라서 재배중인 느타리버섯에 TIF를 처리하는 경우에 더 높은 농도에서도 TIF 에 의한 버섯의 피해는 발생하지 않을 것이며, Fig. 4에서와 같 이 톨라신 활성의 저해효과는 크게 나타날 것이다.

막에 작용하는 펩티드 중 알츠하이머 질병을 일으키는 $\beta$ amyloid $(\beta \mathrm{A})$ 펩티드의 작용에는 분자간의 결합에 의한 원섬유 (fibril) 형성이 중요하다. 여기에 계면활성제인 Sodium dodecyl sulfate는 critical micelle concentration보다 낮은 농도에서 $\beta \mathrm{A}$ 의 원섬유 형성을 촉진시켜 막결합에서의 활성을 증가시킨다 (Shabestari 등, 2016). 계면활성제와 상호작용을 위해서는 펩티 드가 분자내 소수성 부분을 가져야 한다(Sjogren 등, 2005). 펩 티드로 구성된 단백질과 계면활성제의 상호작용은 단백질의 $\alpha$ 나선 구조를 안정하게 하고, 농도에 따라 $\beta$-sheet 구조가 파괴 되는 위험을 감소시킨다(Kuroda 등, 2003). 본 연구를 통해 TIF가 톨라신의 pore 형성에 관여하기 보다는 톨라신의 분자다 중화결합을 방해하여 세포독성을 억제하는 것으로 보여지며, 이 것은 톨라신 독성 저해에 있어 보다 더 분자적 메커니즘을 다 룬 것에 큰 의의가 있다고 생각된다.

\section{초 록}

톨라신은 $1.9 \mathrm{kDa}$ 의 펩티드 독소로서 Pseudomonas tolaasii에 의해 생성되며, 재배중 느타리버섯에 갈반병을 일으킨다. 톨라 신은 막에 pore를 형성하여 세포 구조를 파괴하고, 버섯 재배 의 생산성을 심하게 감소시킨다. 톨라신에 의한 세포독성의 작 용 기작은 완전히 밝혀지지 않았지만, 분자다중화에 의해 세포 막에 채널구조 형성으로 이루어진다. 그러므로, 톨라신과 작용 하는 식품첨가물 중에 톨라신의 다중화결합을 통한 세포막 pore 형성을 저해하는 물질이 있을 것이다. 본 연구에서는, 다양한 물질들이 톨라신의 활성을 저해함을 확인하고, 이들을 톨라신 저해물질(TIF)이라 명명하였다. 대부분의 톨라신 저해물질들은 식품가공과정에 쓰이는 유화제였다. 다양한 종류의 저해물질 중 에 지방산과 에스터 결합한 polyglycerol과 지방산과 에스터 결 합한 sucrose 화합물이 $10^{-4}-10^{-5} \mathrm{M}$ 농도범위에서 톨라신의 세 포독성을 효과적으로 저해하였다. 이러한 저해물질들은 균상재 배하는 느타리버섯에서 갈반병의 발생을 성공적으로 억제하였다.

Keywords 느타리버섯 - 슈도모나스 톨라시 · 톨라신 · 펩티드
독소 · pore 형성

감사의 글 이 논문은 2015년도 충북대학교 학술연구지원사업의 교내연구 비 지원에 의하여 연구되었음.

\section{References}

Cho KH, Kim ST, Kim YK (2006) Inhibitory effect of $\mathrm{Zn}^{2+}$ on tolaasininduced hemolysis. J Korean Soc Appl Biol Chem 49: 281-286

Cho KH, Kim YK (2003) Two types of ion channel formation of tolaasin, a Pseudomonas peptide toxin. FEMS Microbiol Lett 221: 221-226

Cho KH, Park KS, Kim YK (2000) Hemolytic properties of tolaasin causing the brown blotch disease on oyster mushroom. J Korean Soc Agric Chem Biotechnol 43: 190-195

Desai DA, Kukreja GP, Raorane CJ, Patil SB (2016) Partial sequencing of serendipitously isolated antifungal producer, Pseudomonas tolaasii strain GD76 16s ribosomal RNA gene. Int J Curr Microbiol App Sci 5: 455458

Gandy DG (1968) A technique for screening bacteria causing brown blotch of cultivated mushrooms. Annual Report of the Glasshouse Crops Research Institute for $1967,150-154$

Geels FP (1995) Pseudomonas tolaasii control by kasugamycin in cultivated mushroom(Agaricus bisporus). J Appl Microbiol 79: 38-42

Geels FP, van Griensven LD, Rutjens AJ (1991) Chlorine dioxide and the control of bacterial blotch on mushrooms, caused by Pseudomonas tolaasii. In: Maher MJ (ed) Mushroom Science XIII, science and cultivation of edible mushrooms, Balkema, Rotterdam, pp 437-442

Hutchison MI, Johnstone K (1993) Evidence for the involvement of the surface active properties of the extracellular toxin tolaasin in the manifestation of brown blotch disease symptoms by Pseudomonas tolaasii on Agaricus bisporus. Physiol Mol Plant Pathol 42: 273-384

Jolivet S, Voiland A, Pellon G, Arpin N (1995) Main factors involved in the browning of Agaricus bisporus. In: Elliot TJ (ed) Mushroom Science XIV, science and cultivation of edible mushrooms, Balkema, Rotterdam, pp 695-702

Kim JW, Kim KH, Kang HJ (1994) Studies on the pathogenic Pseudomonas causing bacterial disease of cultivated mushroom in Korea: 1. On the causal organisms of the rots of Agaricus bisporus, Pleurotus ostreatus, and Lentinus edodes. Korean J Plant Pathol 10: 197-210

Kim MH, Park SW, Kim YK (2011) Bacteriophages of Pseudomonas tolaasii for the biological control of brown blotch disease. J Korean Soc Appl Biol Chem 54: 99-104

Kuroda Y, Maeda Y, Sawa S, Shibata K, Miyamoto K, Nakagawa T (2003) Effects of detergent on the secondary structures of prion protein peptides as studied by CD spectroscopy. J Pept Sci 9: 212-220

Lee HI, Lee SD, Park KS, Kim YK, Cha JS (1997) Pathogenicity of bacterial isolates from brown blotch-diseased oyster mushrooms in Chungcheungbukdo. J Agric Sci Chungbuk Nat'l Univ 14: 121-132

Lee HJ (2017) Inhibition of green mold diseases on oak mushroom using antifungal peptides. Dissertation, Chungbuk National University

Mu LL, Yun YB, Park SJ, Cha JS, Kim YK (2015) Various pathogenic Pseudomonas strains that cause brown blotch disease in cultivated mushrooms. J Appl Biol Chem 58: 349-354

Nazari M, Kurdi M, Heerklotz H (2012) Classifying surfactants with respect to their effect on lipid membrane order. Biophys J 102: 498-506

Nepal O, Rao JP (2011) Haemolytic effects of hypo-osmotic salt solutions on human erythrocytes. Kathmandu Univ Med J 34: 35-39

Nielson TH, Sorensen C, Tobiasen JB, Andersen C, Christophersen C, Givskov M, Sorensen J (2002) Antibiotic and biosurfactant properties of cycle lipopeptides produced by fluorescent Pseudomonas spp. From the sugar beet rhizosphere. Appl Env Microbiol 68: 3416-3423

Nybroe O, Sorensen J (2004) Production of cyclic lipopeptides by fluorescent 
pseudomonads. In: JL Ramos (ed), Pseudomonas, biosynthesis of macromolecules and molecular metabolism, New York, pp 147-172

Peng JT (1986) Resistance to disease in Agaricus bisporus(lange). Dissertation, University of Leeds

Rainey PB, Brodey CL, Johnstone K (1991) Biological properties and spectrum of activity of tolaasin, a lipodepsipeptide toxin produced by the mushroom pathogen Pseudomonas tolaasii. Physiol Mol Plant Pathol 39: $57-70$

Shabestari MH, Neeuwenoord NJ, Filippov DV, Huber M (2016) Interaction of the amyloid $\beta$ peptide with sodium dodecyl sulfate as a membranemimicking detergent. J Biol Phys 42: 299-315

Shin GC, Jeon NB (1991) Identification of yellow blotch bacteria of oyster mushroom and its biological by antagonistic bacteria. Research Reports of the Rural Development Administration 34, 1-10

Sjogren H, Ericsson CA, Evenas J, Ulvenlund S (2005) Interactions between charged polypeptides and nonionic surfactants. Biophys J 89: 4219-4233
Soler-Rivas C, Moller AC, Arpin N, Olivier JM, Wichers HJ (2001) Induction of a tyrosinase mRNA in Agaricus bisporus upon treatment with a tolaasin preparation from Pseudomonas tolaasii. Physio Mol Plant Pathol 58: 95-99

Soulier L, Foret V, Arpin N (1993) Occurrence of agaritine and $\gamma$-glutaminyl4-hydroxybenzene (GHB) in the fructifying mycelium of Agaricus bisporus. Mycol Res 97: 529-532

Tajalipour S, Hassanzadeh N, Jolfaee HK, Heydari A, Hasemi A (2014) Biological control of mushroom brown blotch disease using antagonistic bacteria. Biocontrol Sci Technol 24: 473-484

Tolaas (1915) A Bacterial disease of cultivated mushrooms. Phytopathol 5: 51-54

Wong WC, Preece TF (1985) Pseudomonas tolaasii in cultivated mushroom (Agaricus bisporus) crops: effects of sodium hypochlorite on the bacterium and on blotch disease severity. J Appl Microbiol 58: 259-267 